\title{
ANÁLISIS METATEÓRICO SOBRE EL OCIO \\ DE LA JUVENTUD CON PROBLEMAS SOCIALES ${ }^{1}$
}

\author{
META THEORETICAL ANALYSIS \\ ON THE LEISURE OF YOUTH WITH SOCIAL PROBLEMS²
}

\author{
ANÁLISE META-TEÓRICA \\ DO ÓCIO EM JOVENS COM PROBLEMAS SOCIAIS
}

\author{
Ana Fernández-García \\ Universidad Nacional de EdUCACIÓn a Distancia, UNED
}

María de Fátima Poza-Vilches

UNIVERSIDAD DE GRANADA

Massimiliano Fiorucci

Università Degli StUdi RoMA TRE

RESUMEN. El presente artículo forma parte de una investigación más amplia ${ }^{3}$ cuyo objetivo final es conocer e interpretar las características actuales del ocio de la juventud en dificultad social, así como sus posibles interrelaciones, en función de variables contextuales e identitarias. Nuestra atención se ha centrado en la revisión y valoración de las investigaciones realizadas sobre las tendencias de ocio juvenil que se están definiendo en la actualidad, especialmente en aquellos jóvenes con problemas sociales. Se persiguen los siguientes objetivos: realizar un análisis metateórico sobre el ocio en jóvenes con problemáticas sociales; y diseñar un mapa de tendencias en ocio juvenil acorde con los hallazgos derivados de investigaciones actuales para aproximarnos a una caracterización de la realidad en la que están insertos. La metodología utilizada para llevar a cabo este trabajo ha consistido en el análisis metateórico de investigaciones relevantes sobre el ocio de los jóvenes. La población estudiada está formada por 86 investigaciones; sin embargo, solo 40 de ellas conforman la muestra final, puesto que han reunido todos los requisitos establecidos: estar publicadas entre los años 2009-2013; poseer una metodología cuantitativa, cualitativa o mixta y, por último que sean investigaciones tanto realizadas en contexto español como a nivel internacional. Se ha utilizado una metodología mixta. El análisis de los datos cuantitativos se ha apoyado en el programa informático SPSS 19.0. Se han realizado análisis descriptivos e inferenciales atendiendo a las siguientes variables: año de publicación; base de datos bibliográfica; ámbito de la publicación y caracterización de la muestra así como el marco metodológico del que parten. Por otro lado, para la información cualitativa se ha llevado a cabo un análisis de contenido con la finalidad de analizar las dimensiones seleccionadas y descubrir las tendencias más relevantes en este campo de investigación. El análisis de los artículos nos ha permitido establecer las dimensiones más relevantes que conforman el amplio abanico de investigaciones sobre el tema, a saber: tec- 
nologías de la información y comunicación (TIC); los valores en la juventud; las formas de ocio juvenil y las relaciones sociales. Así mismo, hemos establecido subcategorías que definen cada dimensión más detalladamente: TIC (usos y abusos); valores (actitudes prosociales y actitudes antisociales); relaciones sociales (tipos, cómo, dónde, con quiénes); y formas de ocio (diurnos y nocturnos). Los análisis realizados aportan una panorámica global así como la tendencia existente en relación al ocio juvenil (hábitos saludables y conductas perjudiciales), especialmente en aquéllos que tienen problemas sociales. Podemos destacar que los y las jóvenes que presentan mayor capacidad prosocial son valorados como mejor adaptados socialmente, puesto que también mantienen unas relaciones sociales más sanas, formas de ocio más saludables y, saben aprovechar las oportunidades que les ofrecen las TIC en beneficio propio y de la comunidad. Finalmente se presentan las líneas futuras de investigación surgidas en los documentos analizados con el propósito de seguir avanzando en este campo y ayudar a la juventud a utilizar su tiempo de ocio de la mejor manera posible.

PALABRAS CLAVE. Tiempo de ocio; Juventud; Problemas sociales; Valores sociales; Análisis documental; Investigación; Redes sociales.

ABSTRACT. This paper is part of a wider research which ultimate goal is to understand and to interpret the current characteristics of the leisure of youth in social difficulties, as well as their interactions, according to contextual and identifiable variables. It is focussed on the revision and assessment of researches done on youth leisure's trends currently defined, mainly on those young with social problems. The pursued objectives are: a meta theoretical analysis on the leisure of youth with social problems; and to design a map of trends on youth leisure according to the findings of the current researches in order to approach their reality. The employed methodology for this work was a meta theoretical analysis of relevant researches on the leisure of young people. The studied population is made up of 86 researches; however, only 40 of them met all the requirements to be at the final sample: to be published between 2009-2013; have a quantitative, qualitative or mixed methodology, and to be developed both in Spain and in an international context. A mixed methodology has been used. The quantitative data analysis was done with the software SPSS 19.0. Descriptive and inferential analyses have been made according to the following variables: year of publication; bibliographic database; publication' scope and sample's characterization as well as their methodological framework. On the other hand, qualitative information was obtained from a content analysis in order to analyse the selected dimensions and discover the most relevant trends in this field of research. The articles analysis has enable us to establish the most relevant dimensions that make up the wide range of research on the subject, namely: technologies of information and communication technology (IT); youth's values; the forms of youth leisure and social relationships. We have also established subcategories to define each dimension deeply: IT (uses and abuses); values (pro-social attitudes and anti-social attitudes); social relations (types, how, where, with whom); and types of leisure (day and night). The analyses performed provide a global view as well as the existing trend in relation to the youth leisure (healthy habits and harmful behaviours), especially in those with social problems. We can highlight that young people presenting more pro-social capacity are valued as better adapted socially, since they also maintain healthy social relationships, healthier forms of leisure, and know to take advantage of the IT opportunities in their own benefit and for the community. At the end of this paper we present future lines of research that have emerged from the analysed documents with the purpose of progressing in this field and of helping young people to use their leisure time in the best possible way.

KEY WORDS. Leisure time; Youth; Social problems; Social values; Documentary analysis; Research; Social networks.

RESUMO. Este artigo é parte de uma pesquisa mais ampla, cujo objetivo final é compreender e interpretar as características atuais do ócio dos jovens com problemas sociais e suas possíveis inter-relações, dependendo de variáveis contextuais e de identidade. A nossa atenção centrou-se na análise e avaliação de

[ 120 ] ANA FERNÁNDEZ-GARCÍA, MARÍA DE FÁTIMA POZA-VILCHES Y MASSIMILIANO FIORUCCI

SIPS - PEDAGOGIA SOCIAL. REVISTA INTERUNIVERSITARIA [1139-1723 (2015) 25, 119-141] TERCERA ÉPOCA 
pesquisas sobre tendências do ócio juvenil na atualidade, especialmente em jovens com problemas sociais. Os objetivos deste trabalho são: realizar uma análise meta-teórica do ócio em jovens com problemas sociais; e desenhar um mapa de tendências do ócio dos jovens de acordo com os resultados da pesquisa em que se aborda uma caracterização da realidade em que estão inseridos. A metodologia utilizada para realizar esse trabalho tem sido a análise meta-teórica de pesquisas relevantes sobre ócio juvenil. A população do estudo é constituída por 86 pesquisas; no entanto, apenas 40 delas compõem a amostra final, pois estas cumprem todas as seguintes exigências: pesquisas publicadas entre 2009 a 2013; possuir metodologia quantitativa, qualitativa ou mista e, finalmente, que as investigações tenham sido conduzidas tanto no âmbito espanhol e internacional. Para a realização desta pesquisa foi utilizada uma metodologia mista. A análise quantitativa dos dados foi apoiada pelo software SPSS 19.0. Houve análise descritiva e inferencial de acordo com as seguintes variáveis: ano de publicação; base de dados bibliográficos; campo da publicação e caracterização da amostra e o marco metodológico original de determinada pesquisa. Além dos dados qualitativos foi realizada a análise de conteúdo, a fim de analisar as dimensões selecionadas e encontrar as tendências mais relevantes neste campo de pesquisa. A análise dos artigos permitiu estabelecer as dimensões mais relevantes que compõem a vasta gama de pesquisas sobre o assunto, a saber: tecnologia da informação e comunicação (TIC); valores na juventude; formas juvenis de ócio e relações sociais. Além disso, foram estabelecidas subcategorias que definem cada uma das dimensões mais detalhadamente: TIC (uso e abuso); valores (atitudes pró-sociais e atitudes anti-sociais); relações sociais (tipos, como, onde, com quem); e formas de entretenimento (dia e noite). As análises forneceram uma visão abrangente e uma tendência em relação ao ócio juvenil (hábitos saudáveis e comportamentos prejudiciais), especialmente aqueles com problemas sociais. Podemos notar que os jovens que estão em maior capacidade pró-sociais são classificados como mais ajustados socialmente, uma vez que eles também mantêm boas relações sociais, formas de ócio mais saudáveis e sabem como aproveitar as oportunidades oferecidas pelas TIC em benefício próprio e da comunidade. Finalmente, se apresentam as intensões em desenvolver pesquisas futuramente a partir dos documentos analisados, a fim de promover o progresso neste campo e ajudar os jovens a usar seu tempo de ócio da melhor maneira possível.

PALAVRAS-CHAVE. Lazer; Juventude; Problemas sociais; Valores sociais; Análise de documentos; Pesquisa; Redes sociais.

\section{Introducción}

Dados los cambios sociales, económicos y tecnológicos que se van produciendo, el fenómeno del ocio también se ha ido modificando en cuanto a su consideración, distribución, espacios y tiempos en los que se desarrolla, repercutiendo, además, en nuevas formas de desarrollo personal y social supeditadas, en muchas ocasiones, a las posibilidades económicas de las que se parte (Cuenca, 1998).

En el Informe de la Juventud en España (INJUVE, 2012) se expone que la población juvenil en la actualidad conforma un colectivo caracterizado por una situación educativa, socioeconómica y relacional que diseña su silueta como grupo diverso y heterogéneo y con intervalo de edad no uniforme. Los problemas o cuestiones de la sociedad en general

\section{Introduction}

Given the current social, economic and technological changes, the phenomenon of leisure is also changing in terms of its consideration, distribution, spaces and moments of development, influencing in the new ways of personal and social development subjected, many times, to the own economic possibilities (Cuenca, 1998).

The Informe de la Juventud en España (INJUVE, 2012) exposed that the current youth population has a relational, socio-economic and educational situation as a diverse and heterogeneous group and with a non-uniform age range. This collective is affected in a more specific and intense way by the society general problems or questions, as the current economic crisis: it has 
afectan a este colectivo juvenil de manera específica y más intensa, como es el caso de la crisis económica actual: ha aumentado su tiempo libre, desempleo, consumismo y uso de las TIC como medio relacional. Así mismo, están incrementando su periodo formativo a la vez que retrasan su emancipación familiar. Llevan asociados comportamientos sociales comunes guiados por una fuerte autonomía individual que tiene como objetivo redefinir su proyecto vital para el ejercicio de su plena ciudadanía. Para este colectivo, "el tiempo libre es un escenario abierto en el que cabe tanto la alienación consumista y la pasividad, como el desarrollo de la creatividad y la promoción de determinados valores como la solidaridad, la justicia, el respeto y la no discriminación" (Marañón Basarte, citado por Vega Moreno en Sarrate Capdevila, 2014:413).

Bajo esta singularidad, dentro de este grupo de población hay un colectivo más vulnerable y mermado por el contexto socioeconómico y vital en el que está inmerso y para el que hay que pautar estrategias de intervención que posibiliten su inclusión y su transición normalizada a la vida adulta. Para favorecer el trabajo con esta juventud con problemática social (Montes, 2008), hay que apostar por políticas afirmativas de plena ciudadanía juvenil que incidan en los diferentes ámbitos que conforman la realidad juvenil bajo dos perspectivas: trabajar en aquellos ámbitos relacionados con las condiciones de vida de la juventud, de su capacidad de autonomía y de emancipación, e incidir en aquellas áreas que desarrollan aspectos de la propia condición juvenil entre las que se encuentran la dinamización, participación y promoción de un ocio educativo, entre otras.

Partiendo de esta panorámica, este artículo pretende exponer la relevancia del ocio como área de intervención para el colectivo juvenil y estudiar la incidencia en su propio desarrollo. El análisis metateórico que se detalla en el presente trabajo marca las tendencias actuales juveniles en este campo para poder plantear estrategias de intervención y buenas prácticas innovadoras, renovadas y eficaces, que reviertan en la mejora de la calidad de vida del colectivo juvenil y su contexto de referencia.

Como objetivos de investigación, podemos detallar los siguientes:

1. Realizar un análisis metateórico sobre el ocio en jóvenes con problemáticas sociales. increased their free time, unemployment, consumerism, and the use of the IT for communication. Likewise, their training period is being increased and their family emancipation is delayed. This collective have a social behaviour guided by a strong individual autonomy that aims to redefine their vital project for the exercise of their full citizenship. For them, "the leisure time is an open stage in which both consumer alienation and passivity fits, as well as the development of creativity and the promotion of certain values such as solidarity, justice, respect and non-discrimination" (Marañón Basarte, quoted by Vega Moreno in Sarrate Capdevila, 2014:413).

Within them, there is group more vulnerable and diminished by their socio-economic and vital context that requires intervention strategies that enable their inclusion and a standard transition to adult life. To encourage the work with these young people with social problems (Montes, 2008), affirmative social polices of full youth-citizenship affecting different areas that make up the youth reality under two perspectives must be implemented: to work in those areas related to the youth's life conditions, their capacity for autonomy and emancipation, and to influence those areas that develop aspects of the young condition itself which include boosting participation and promotion of educational leisure, among others.

Based on this view, this paper aims to explain the relevance of leisure as an intervention area for young people and to study its incidence in their development. The meta theoretical analysis of this paper marks current youth trends in this field in order to propose intervention strategies as well as innovative, effective, and renovated practices which improve young people's quality of life and their reference context.

Those are the research's aims:

1. To develop a meta theoretical analysis on the leisure of young people with social problems.

2. To design a map of trends on youth leisure matching the findings of the current researches in order to approach their reality.

[ 122 ] ANA FERNÁNDEZ-GARCÍA, MARÍA DE FÁTIMA POZA-VILCHES Y MASSIMILIANO FIORUCCI 
2. Diseñar un mapa de tendencias en ocio juvenil acorde con los hallazgos derivados de investigaciones actuales para aproximarnos a una caracterización de la realidad en la que están insertos.

\section{Metodología}

La metodología utilizada para llevar a cabo este trabajo ha consistido en el análisis metateórico de investigaciones realizadas sobre las tendencias del ocio juvenil que están definiéndose en la actualidad, especialmente en aquéllos con problemática social. Cortés del Moral (2000) define la metateoría como un campo disciplinar que se ocupa del estudio de la teoría, es decir, de los saberes acumulados en un área particular de conocimiento científico o humanístico. Por su parte, Gómez Villalpando (2009) expone que la metateoría es un medio para obtener una comprensión más profunda de la teoría, surgiendo del estudio meticuloso de los planteamientos de otros teóricos. Este procedimiento, por tanto, permite reducir una gran cantidad de información agrupándola en categorías, y limita la probabilidad de que los resultados de las diferentes investigaciones puedan atribuirse al azar, obteniendo una panorámica de conjunto de las tendencias surgidas en las mismas.

Esta metodología se ha aplicado a un conjunto de investigaciones que estudian la misma problemática y que comparten las principales variables dependientes e independientes. Los estudios previos, insertos en un ámbito de investigación dado, en nuestro caso en las Ciencias Sociales, nos ayudan a comprender aspectos globales del fenómeno estudiado, característica de la que carecen los estudios individuales. Su finalidad es analizar, sintetizar e integrar dichos resultados.

El recorrido conceptual e investigativo que se presenta en este trabajo, pretende establecer un mapa situacional de la realidad juvenil en el espacio de ocio con el fin de posibilitar datos e información relevante que guíen el diseño y desarrollo de buenas prácticas en este campo.

Bajo este prisma, este estudio se sustenta en el establecimiento de una red dimensional sobre el ocio juvenil fruto de dos procesos de análisis: el deductivo y el inductivo.

\section{Methodology}

The methodology used to carry out this work consisted in the meta theoretical analysis of researches on currently youth leisure trends, especially in those with social problems. Cortés del Moral (2000) defines a meta theory as a theory whose subject matter is some theory, i.e., the accumulated knowledge in a particular area of scientific or humanistic knowledge. Gómez Villalpando (2009) exposes that meta theory is a means for obtaining a deeper understanding of the theory, from the meticulous study of other theorists' approaches. Therefore, this procedure allows to reduce the large amount of information by grouping it into categories, which limits the likelihood of that various researches' results can be attributed to fate, so an overview of the emerged trends is obtained.

This methodology has been applied to several researches studying the same issue, which share the main dependent and independent variables. Previous studies on this field (Social Sciences) help us to understand global aspects of the phenomenon under study, a feature without individual studies performed. Its purpose is to analyse, synthesize and integrate these results.

The conceptual and investigative path of this work, aims to establish a situational map of the youth reality in the leisure area in order to obtain data and relevant information that guide the design and development of good practices in this field.

Through this point of view, this study is based on the establishment of a dimensional network on youth leisure as a result of two processes of analysis: inductive and deductive. 
PROCESO DEDUCTIVO: “Las conclusiones deductivas son necesariamente inferencias hechas a partir de un conocimiento que ya existe...El razonamiento deductivo puede organizar lo que ya se conoce y señalar nuevas relaciones conforme pasa de lo general a lo específico, pero sin que llegue a constituir una fuente de verdades nuevas" (Dávila, 2006:185). Este marco de análisis teórico nos ha posibilitado la definición de un mapa dimensional parcial centrado en el análisis documental sobre la temática de ocio en el colectivo juvenil que ha hecho posible, a su vez, la identificación de categorías que se han marcado como relevantes en los diferentes documentos técnicos que guían actualmente la práctica profesional en este ámbito: Carta Internacional para la Educación del Ocio (World Leisure And Recreation Association, 1993), Pacto Europeo para la Juventud (2005), Manifiesto por un ocio inclusivo (Instituto de Estudios de Ocio, Universidad de Deusto, 2003), informes de investigación sobre la cuestión objeto
DEDUCTIVE PROCESS: "The deductive conclusions are necessarily inferences made from a knowledge that already exists...Deductive reasoning can organise what is already know and points out new relationships from general to specific, but without being a source of new truths" (Dávila, 2006:185). This theoretical analysis framework has made possible the definition of a partial-dimensional map centred on the documentary analysis on the subject of leisure of young people which has enabled the identification of categories that have been marked as relevant for different technical documents that currently guide the professional practice in this field: World Leisure And Recreation Association (1993), European Youth Pact (2005), Manifesto for inclusive leisure (Institute of Leisure Studies, University of Deusto, 2003), reports of research on the subject matter of the study carried out by the Youth Observatory in Spain. Leisure and free time.

Figura 1. Proceso de análisis deductivo en la definición e dimensiones

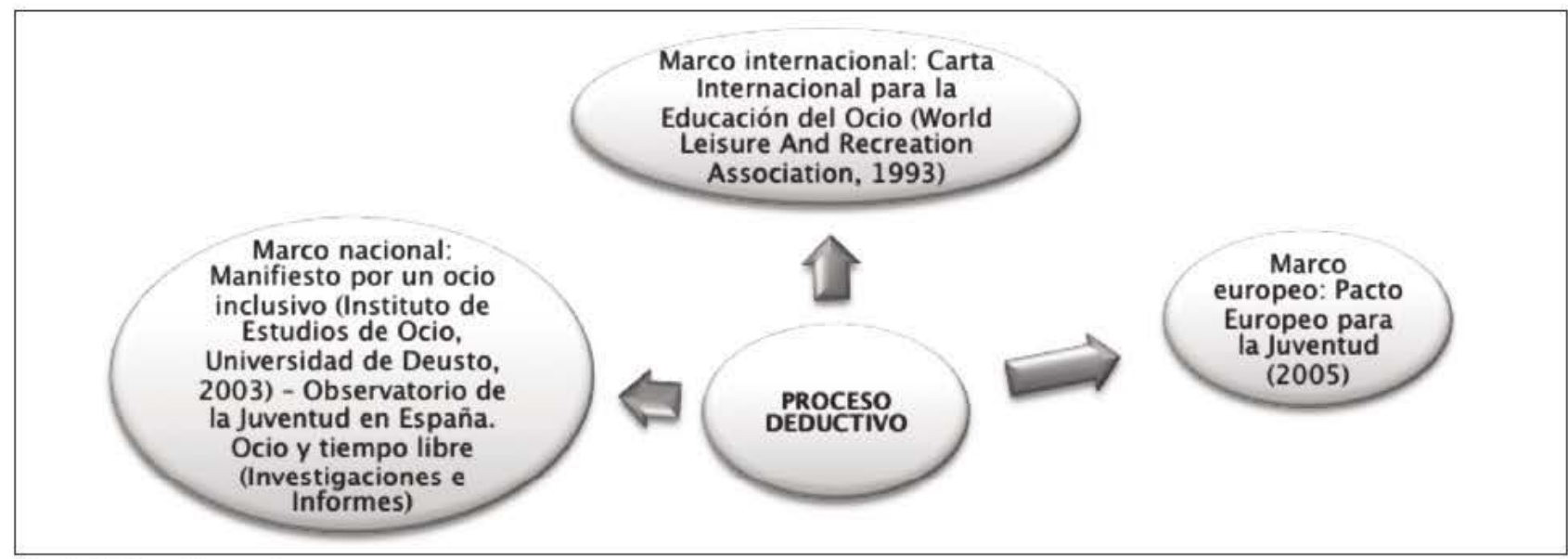

Fuente: Elaboración propia.

Figure 1. Deductive analysis process on the definition of dimensions

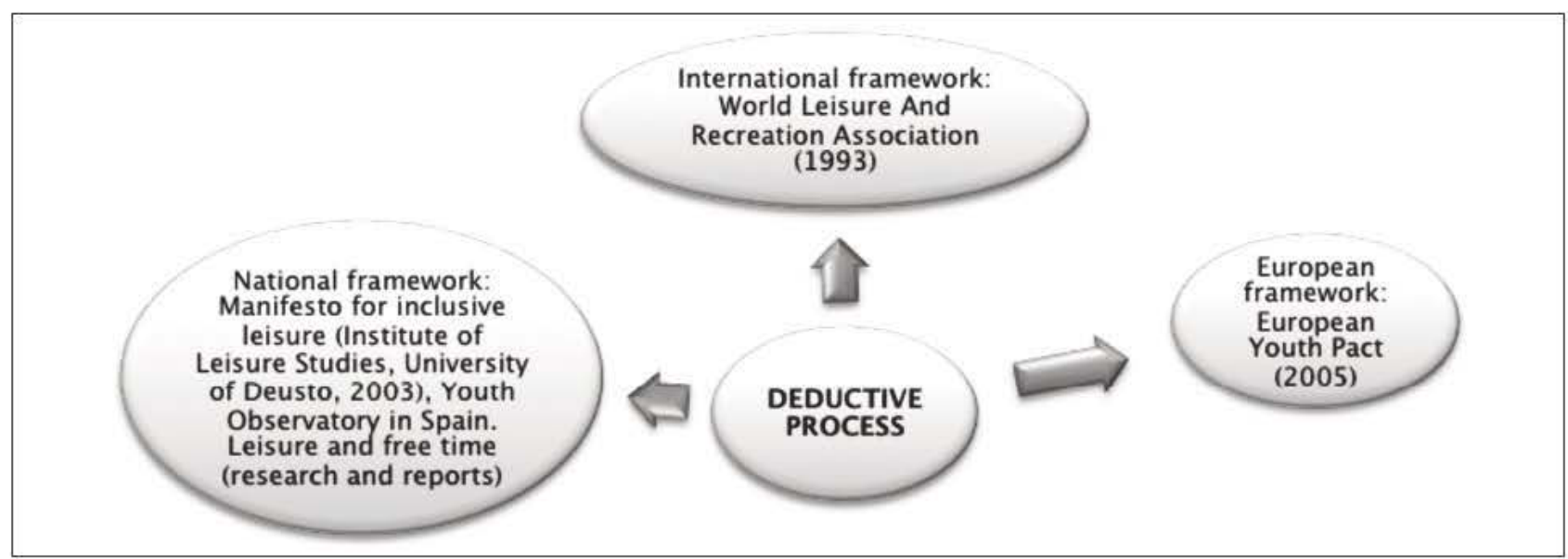

Source: Personal compilation.

[ 124 ] ANA FERNÁNDEZ-GARCÍA, MARÍA DE FÁTIMA POZA-VILCHES Y MASSIMILIANO FIORUCCI SIPS - PEDAGOGIA SOCIAL. REVISTA INTERUNIVERSITARIA [1139-1723 (2015) 25, 119-141] TERCERA ÉPOCA 
de estudio realizados por el Observatorio de la Juventud en España. Ocio y tiempo libre.

PROCESOINDUCTIVO: “Método que parte de largas series de observaciones y experimentos y se basan en ellos" (Popper, 1983: 79). Desde esta conceptualización, el sistema dimensional caracterizado en el proceso deductivo se ha matizado desde el inductivo, marcado por el estudio analítico desarrollado y por el proceso de generalización de resultados al que hemos tendido con la realización de este diagnóstico descriptivo.
INDUCTIVE PROCESS: "Method that part from a series of observations and experiments based on the socalled" (Popper, 1983: 79). From this conceptualization, the dimensional system characterized in the deductive process has been qualified from the inductive one, marked by the development of an analytical study and the generalization of results process to which we have tended with the realization of this descriptive diagnosis.

Figura 2. Proceso de análisis inductivo

\section{ESTUDIO \\ EMPÍRICO}

\section{GENERALIZACIÓN DE RESULTADOS}

\section{PROCESO} INDUCTIVO

Fuente: Elaboración propia.

Figure 2. Process of inductive analysis

\section{EMPIRICAL STUDY}

\section{GENERALIZATION OF RESULTS}

Source: Personal compilation.

El proceso sistemático llevado a cabo consta de cuatro fases:

1. Definición de las dimensiones más importantes que caracterizan el ocio juvenil: se han consultado bases de datos relevantes que contienen revistas especializadas sobre los hábitos de ocio de este colectivo de cara a seleccionar las investigaciones objeto de estudio, a saber: DIALNET, ERIC, ISOC y REDALYC. Por su parte, para la elección de las revistas es-
The systematic process carried out consists of four phases:

1. Definition of the most important dimensions that characterize the youth leisure: relevant databases (DIALNET, ERIC, ISOC and REDALYC) containing magazines on leisure activities of this collective in order to select the research object of study has been consulted. Moreover, three criteria were applied for the selection of the specialized magazines: a) to be 
pecializadas se han definido tres requisitos de selección: a) estar publicadas entre los años 2009-2013; b) poseer una metodología cuantitativa, cualitativa o mixta y, c) ser de ámbito nacional e internacional (perfilado en dos niveles contextuales; ámbito nacional para referirnos al contexto español, ya sea local, regional o nacional y ámbito internacional para caracterizar las autorías de origen no español).

La búsqueda se ha organizado a partir del cruce de tres descriptores clave: ocio -juventud-dificultad social. La interrelación de estas tres palabras clave, ha dado como resultado cuatro ejes de investigación analítica que, al mismo tiempo, constituyen las dimensiones más importantes de nuestra investigación: 1) Uso de las TIC; 2) Relaciones sociales juveniles; 3) Valores de la juventud; 4) Formas de ocio juvenil. Finalmente, de cara a establecer un mapa de tendencias en materia de ocio juvenil, ha sido fundamental matizar la realidad de este colectivo para cada una de estas dimensiones, definiendo para ello, microcategorías para explicar, caracterizar y contextualizar la acción juvenil posibilitando el análisis metateórico pretendido.

El número de artículos encontrados en esta primera fase ha alcanzado la cifra de ochenta y seis, que forman la población objeto de investigación.

2. Filtrado de documentos encontrados en la fase de búsqueda: para ello, hemos establecido el siguiente procedimiento:

a. Campos sobre los que se aplica la búsqueda: título, resumen, descriptores.

b. Utilización de la Lógica Booleana para la búsqueda combinada de conceptos.

c. Operadores de proximidad o posición: ej. Jóvenes "WITH" valores. En este caso, solo se han recuperado aquellos registros que han contenido en el mismo documento (título, resumen) los dos términos. Algunos ejemplos de combinaciones utilizadas han sido: (Juventud y ocio nocturno); (Jóvenes y actitudes prosociales); (Juventud y redes sociales).

3. Elección de artículos según los siguientes criterios: published between 2009-2013; b) to have a quantitative, qualitative or mixed methodology and, c) to be at a national and international level (divided into two contextual levels; national for the Spanish context, either locally, regionally or nationally, and internationally to characterize the non-Spanish authorship).

The search was organized from three key descriptors: leisure - youth - social difficulty. The interrelation of these three key words, has resulted in four axes of analytical research that, at the same time, constitute the most important dimensions of our research: 1) use of IT; 2) youth social relations; (3) youth's values; (4) forms of youth leisure. Finally, in order to establish a map of trends for youth leisure, clarifying the reality of this group for each of these dimensions has been crucial. It defined micro-categories to explain, characterize and contextualize the youth action enabling the expected meta theoretical analysis.

The number of items found in this first stage was eighty-six, forming the studied population.

2. Filtration of documents found in the search stage: to this end, the following procedure was established:

a. Fields on which the search applies: title, abstract and key words.

b. Use of the Boolean logic for the combined search of concepts.

c. Proximity or position operators: ex. Young people "WITH" values. In this case, just those records containing both terms in the same document (title, abstrac) have been recovered. Some examples of the used combinations are: (Youth and night life); (Youth and prosocial attitudes); (Youth and social networks).

3. Choice of items according to the following criteria: 
Figura 3. Mapa dimensional con subcategorías de análi

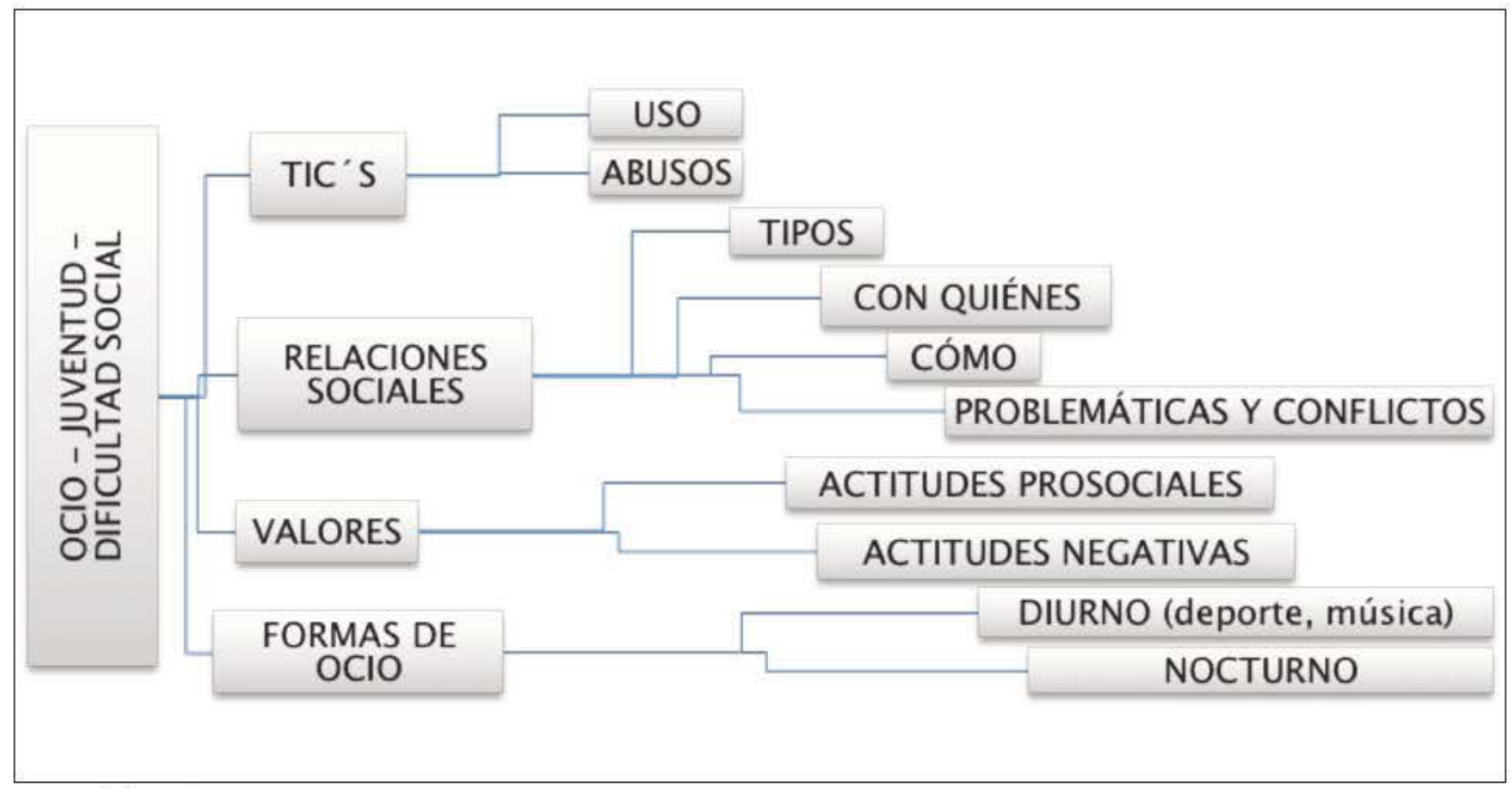

Fuente: Elaboración propia.

Figure 3. Dimensional map with subcategories of analysis

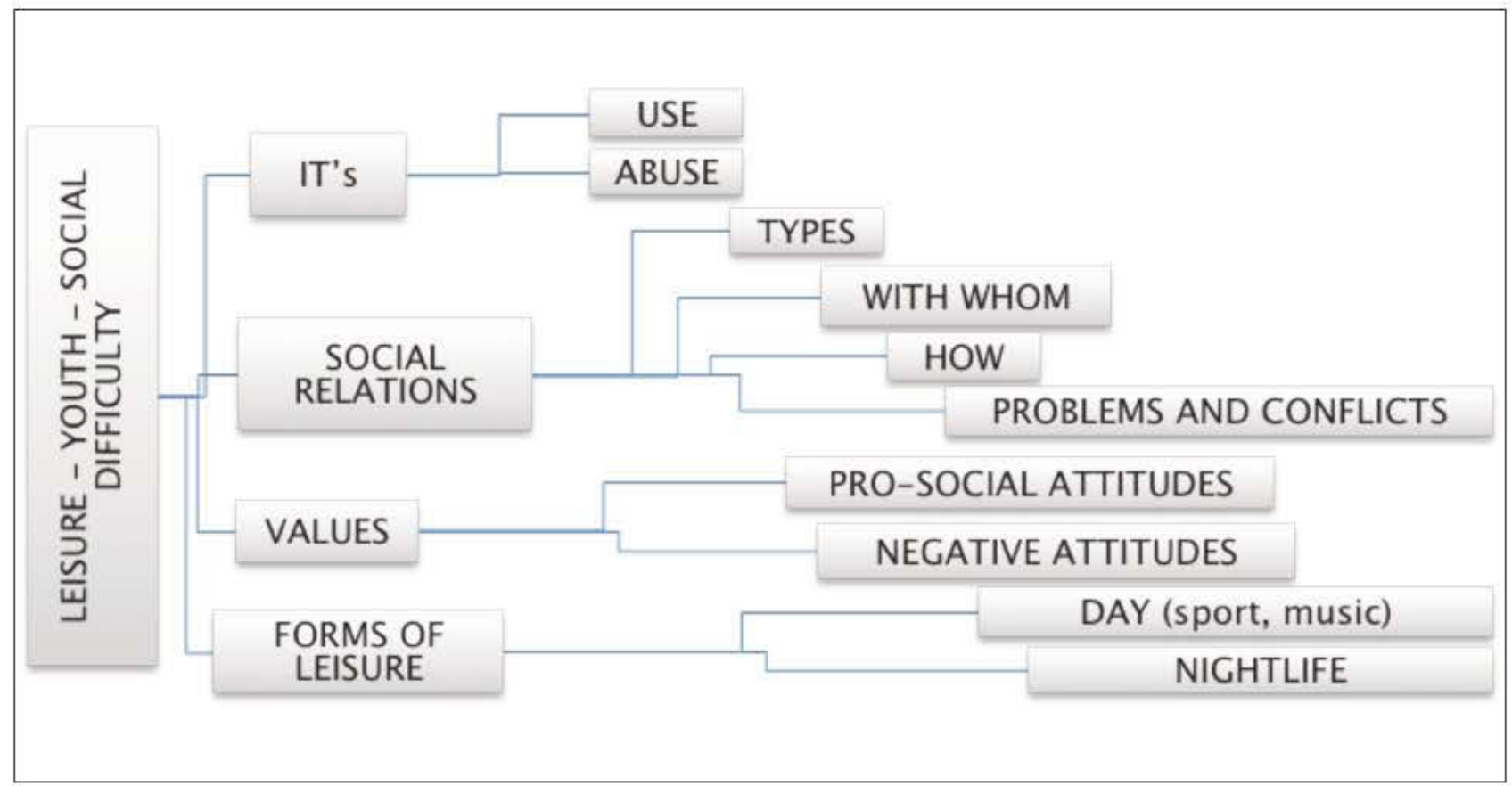

Source: Personal compilation.

a. Criterio de pertinencia: diseño de subcategorías más pertinentes a la dimensión correspondiente.

b. Criterio de suficiencia: Análisis de los artículos que se ajustan suficientemente al tema de investigación: Son cuarenta los que cumplen los requisitos de selección y conforman la muestra de estudio. a. Relevance criteria: design of the most relevant subcategories to the corresponding dimension.

b. Sufficiency adequacy: Analysis of articles that conform sufficiently the research subject: Forty of them meet the selection requirements and comprise the study sample. 
4. Análisis de contenido de los artículos que engloban la muestra del estudio cara a definir la tendencia actual sobre ocio juvenil: descubrir hábitos saludables y conductas más perjudiciales en la juventud, especialmente en aquella con problemáticas sociales; así como perfilar propuestas de acción que guíen las buenas prácticas en este campo.

Respecto a la tarea analítica, ésta se ha ejecutado desde dos acciones: (1) análisis cuantitativo de los artículos seleccionados desde análisis descriptivos e inferenciales atendiendo a las siguientes variables: año de publicación; base de datos; ámbito de la publicación, caracterización de la muestra y marco metodológico de referencia; (2) análisis de contenido de los artículos seleccionados atendiendo a las dimensiones definidas con la finalidad de describir la tendencia actual en este campo de investigación.

\section{Resultados}

La presentación de los resultados se lleva a cabo teniendo en cuenta, en primer lugar, la población objeto de estudio, lo que permite obtener un perfil global de la temática analizada y procediendo, posteriormente, a la descripción más exhaustiva de la muestra seleccionada en esta investigación.

El $25,6 \%$ de las publicaciones que conforman la población objeto de estudio se refieren a las TIC y un $23,3 \%$ se relaciona con los valores sociales de la juventud. Por su parte, un $23,3 \%$ estudian las relaciones sociales entre la juventud $y$, finalmente un $27,9 \%$ analizan las diversas formas de ocio que caracterizan a este colectivo. De esta población, el $47,7 \%$ corresponde a la muestra final investigada.

En cuanto al año de publicación, el $18,6 \%$ de las investigaciones fueron publicadas en el año 2009; el $14 \%$, en el año 2010 ; un $48,8 \%$ del total de la población, entre los años 2011 y 2012 y un $18,6 \%$ corresponden al año 2013.

En relación al ámbito de procedencia, el $48 \%$ de los artículos analizados pertenecen al ámbito nacional y el 38\% restante al internacional.

Respecto a las bases de datos bibliográficas, el porcentaje más elevado de artículos se encuentra en DIALNET, que alcanza el 39,5\%, seguido de ISOC
4. Content analysis of articles covering the study sample to define the current trend on youth leisure: discover healthy habits and more harmful behaviours in youth, especially those with social problems; as well as outline action proposals leading to good practices in this field.

Regarding the analytical task, this was run from two actions: (1) quantitative analysis of the selected articles from a descriptive and inferential analysis according to the following variables: year of publication; database; scope of publication, characterization of the sample and methodological frame of reference; (2) analysis of the content of the selected articles according to the dimensions defined in order to describe the current trend in this field of research.

\section{Results}

The presentation of results takes into account, at first, the study population, enabling to obtain an overall profile of the analysed theme, and then proceeding to a more comprehensive description of the sample in this research.

$25.6 \%$ of the publications that make up the study population relate to IT and $23.3 \%$ of them related to the social values of the youth. Furthermore, $23.3 \%$ of them study social relationships among the youth and, finally, $27.9 \%$ discusses the various forms of leisure that characterize this group. Of this population, $47.7 \%$ corresponds to the final sample investigated.

As for the year of publication, $18.6 \%$ of investigations were published in 2009; $14 \%$, in 2010; $48.8 \%$ of the total population, between 2011 and 2012 and $18.6 \%$ correspond to the year 2013 .

In relation to the area of origin, $48 \%$ of the analysed articles belong to a national level and the remaining 38\% are international.

Regarding the bibliographic databases, the highest percentage of articles can be found at DIALNET, reaching $39.5 \%$, followed by ISOC with $31.4 \%$. REDALYC achieved a percentage of $17.4 \%$ and finally ERIC reaches $11.6 \%$. 
Figura 4. Producción documental por dimensiones y año

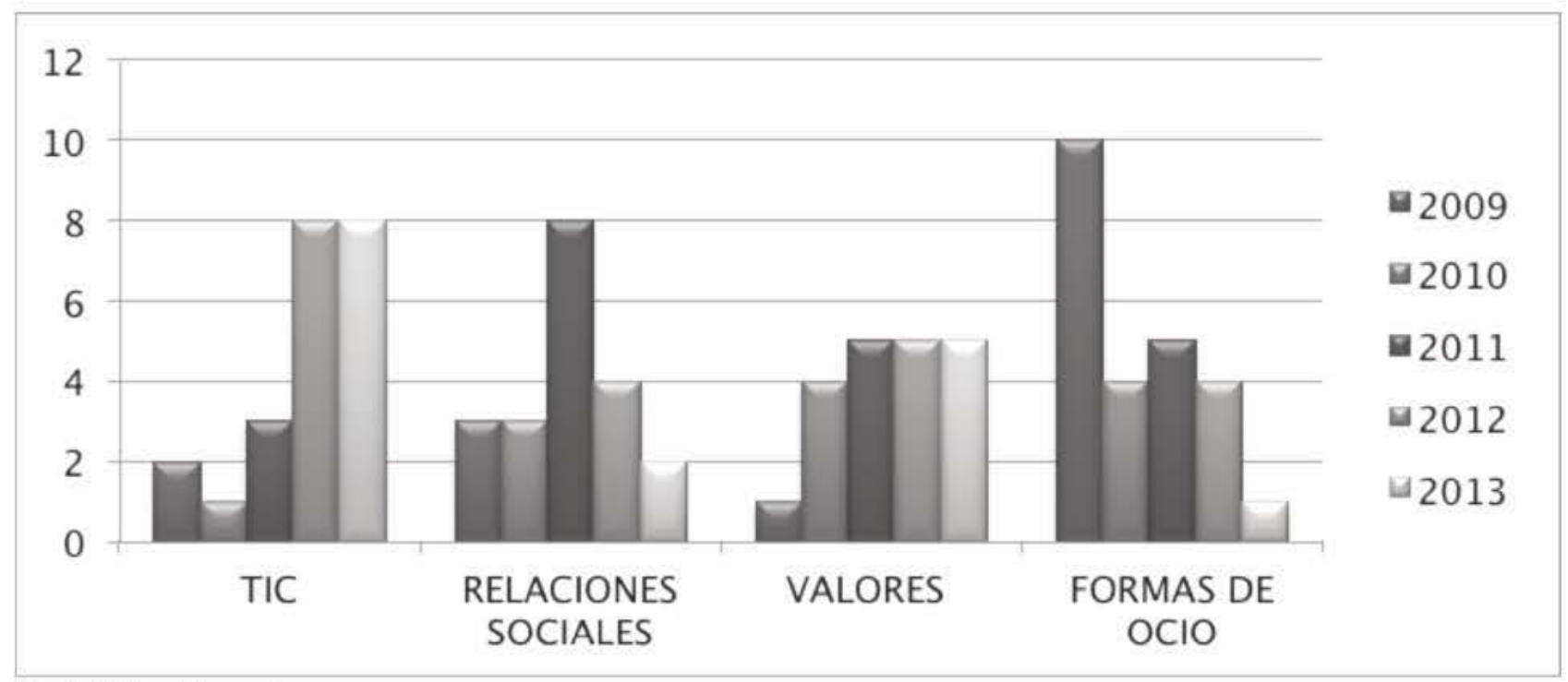

Fuente: Elaboración propia.

Figure 4. Documentary production by dimensions and year

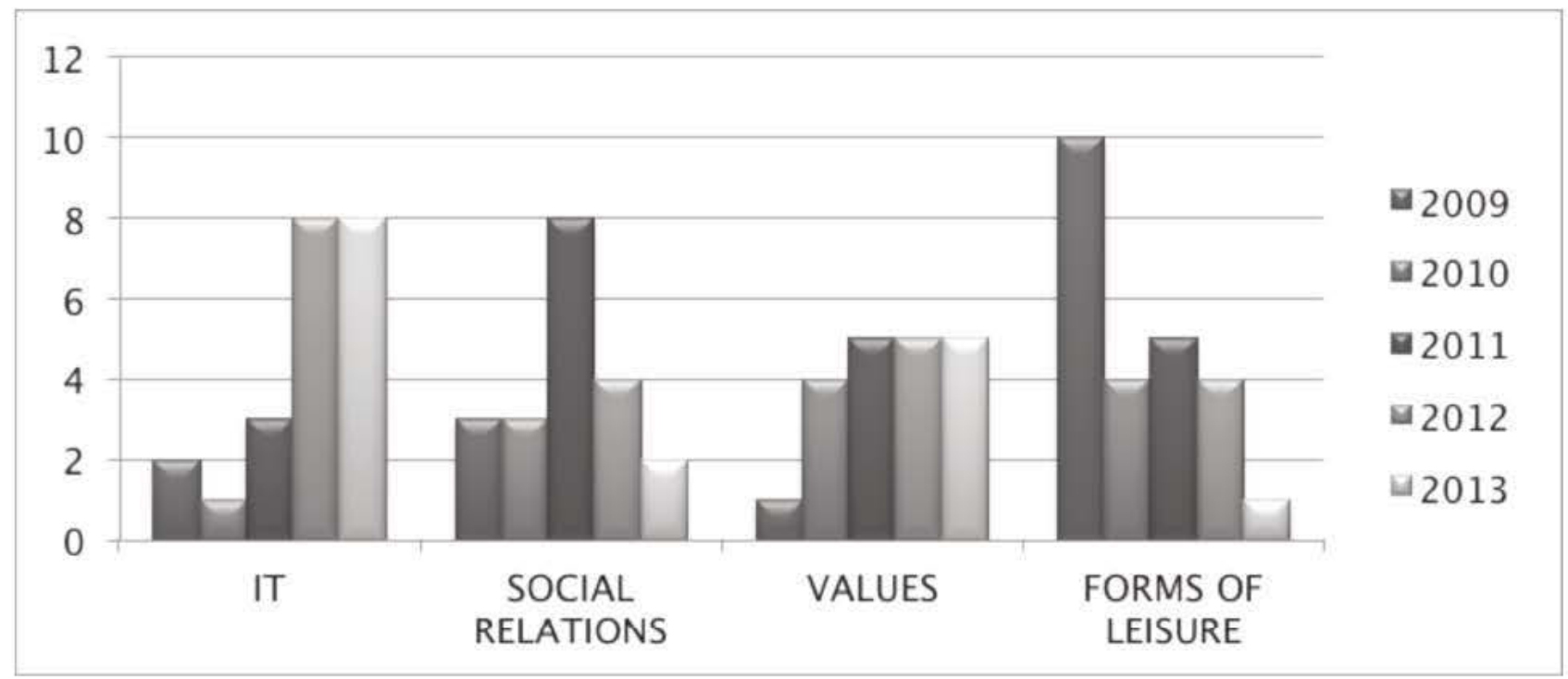

Source: Personal compilation.

con un $31,4 \%$. REDALYC logra un porcentaje del $17,4 \%$ y por último ERIC alcanza un $11,6 \%$.

Así mismo, se han cruzado (mediante un análisis de contingencia) las variables "año de publicación" y "dimensiones". El grado de significación obtenido mediante el estadístico chi-cuadrado ha alcanzado un valor de (,015), que demuestra la existencia de diferencias significativas entre las variables analizadas. Se ha detectado un porcentaje más amplio de investigaciones que analizan las TIC en años más recientes (20122013), en comparación a años anteriores. El estudio de los valores sociales en la juventud repunta en el año 2017; en tanto que el año 2009 ha sido más prolíico en
Likewise, the variables "year of publication" and "dimensions" have been crossed (through a contingency analysis). The satisfaction level obtained by using the Chi-square statistical has reached a value of (.015), which demonstrates the existence of significant differences between the analysed variables. A wider range of researches analysing the IT have been detected in the last years (2012-2013), in comparison to previous years. The study of social values on young people increases in 2011; while the year 2009 has been most prolific in research devoted to the study and analysis of the forms of leisure in this collective (see figure 4 ). 
investigaciones dedicadas al estudio y análisis de las formas de ocio en este colectivo (ver figura 4).

Partiendo de la población total de referencia para este estudio, la muestra final, compuesta por publicaciones que han cumplido los requisitos de selección previamente establecidos y detallados anteriormente en metodología, corresponde al $47,7 \%$ del total. Han sido 10 los artículos seleccionados para cada dimensión, con un total de 40 artículos como muestra final.

Un 40\% de estos artículos, están alojados en la base de datos DIALNET; un 32,5\% se entrecruzan en la opción DIALNET+ISOC; un 15\% tienen presencia en REDALYC; un $10 \%$ solo en ISOC y solo un $2,5 \%$ de los documentos analizados están referenciados en la base de datos internacional ERIC.

Su distribución temporal pone de manifiesto una elección de la muestra actualizada en el tiempo con porcentajes iguales en los años 2009, 2010 y 2012 con un $17,5 \%$ cada uno; publicados en el 2011 , un $20 \%$, y producidos en 2013 , un $27,5 \%$.

La mayoría de los artículos están adscritos a una revista de corte nacional (70\%) del tipo Athenea Digital, Análisi Monográfic, Revista de Investigación Educativa, Adicciones o Comunicar, entre otras. La muestra internacional corresponde a un $30 \%$ en revistas como: Psychology of Sport and Exercise, Journal of Criminal Justice o European Journal of Education and Psychology Justice.

También la autoría de los artículos muestra porcentajes similares. Un 65\% de autores pertenecen al marco nacional, un 30\% al internacional y un $5 \%$ corresponde a artículos con autoría procedente de ambos contextos, nacional e internacional.

A nivel metodológico, el 70\% de los artículos analizados parte de una metodología cuantitativa. El $30 \%$ restante se distribuye en un $10 \%$ de corte cualitativo y un $20 \%$ de metodología mixta (cuantitativa y cualitativa). A nivel de instrumentos, el $65 \%$ utiliza la técnica de encuesta con el cuestionario fundamentalmente, y un 15\%, la entrevista. El resto de porcentajes se distribuyen en estudios con instrumentos de recogida de información mixta en la que se utilizan cuestionarios, entrevistas y grupos de discusión.

Hay heterogeneidad respecto al tamaño muestral, recogiéndose la siguiente distribución de muestras en la que se identifica que más de la mitad de los artículos (55\%) tienen un tamaño muestral inferior a 500.
Based on the total reference population for this study, the final sample, composed by publications that have meet the selection requirements previously established and detailed in methodology, corresponds to $47.7 \%$ of the total. For each dimension 10 articles have been selected, with a total of 40 articles as final sample.

$40 \%$ of these articles are hosted at DIALNET database; a $32.5 \%$ at DIALNET+ISOC; $15 \%$ have a presence in REDALYC; $10 \%$ only in ISOC and only $2.5 \%$ of the analysed documents are referenced at the international database ERIC.

Their temporal distribution reveals a choice of the sample updated with the same percentages as those of 2009, 2010 and 2012 with $17.5 \%$ each; published in $2011,20 \%$, and $27.5 \%$ produced in 2013.

Most of the items are assigned to a national level magazine (70\%) similar to Athenea Digital, Análisi Monográfic, Revista de Investigación Educativa, Adicciones o Comunicar, among others. 30\% are international magazines such as: Psychology of Sport and Exercise, Journal of Criminal Justice or European Journal of Education and Psychology Justice.

Also the articles authorship shows similar percentages. $65 \%$ of authors are from a national framework, 30\% international and 5\% corresponds to articles from both contexts, national and international.

At a methodological level, $70 \%$ of the analysed articles are based on a quantitative methodology. The remaining $30 \%$ is distributed in a qualitative range $10 \%$ and $20 \%$ of mixed methodology (quantitative and qualitative). At instrument level, 65\% used mainly survey with questionnaire technique, and $15 \%$, the interview. The rest of percentages are distributed in studies with instruments for mixed data collection in which questionnaires, interviews and discussion groups are used.

There is heterogeneity in terms of sample size. It was collected following distribution of samples, revealing that more than half of the articles (55\%) have a sample size under 500 . 
Figura 5. Distribución del tamaño muestral

\begin{tabular}{lcc}
\hline & Frecuencia & Porcentaje \\
\hline Menos de 100 & 8 & 20,0 \\
\hline De 101 a 500 & 14 & 35,0 \\
\hline De 501 a 1000 & 6 & 15,0 \\
\hline De 1001 a1500 & 7 & 17,5 \\
\hline De 1501 a 2000 & 1 & 2,5 \\
\hline Más de 2001 & 3 & 7,5 \\
\hline No se define & 1 & 2,5 \\
\hline Total & 40 & 100,0 \\
\hline
\end{tabular}

Fuente: Elaboración propia.

Por último, la duración de las investigaciones no es un dato que se desprenda de muchos de los artículos analizados. En los que se detalla hay un $20 \%$ de investigaciones que oscila entre 1 y 3 meses, un $17,5 \%$ que plantean investigaciones de menos de 1 mes, y más de 3 meses es el tiempo que señala el $15 \%$ de los artículos.

Los resultados expuestos de carácter cuantitativo, nos han permitido caracterizar la población y la muestra objeto de estudio así como definir los perfiles metodológico que han guiado las investigaciones analizadas. A continuación y, a modo de discusión, se exponen los resultados cualitativos. Este análisis metateórico nos ha posibilitado caracterizar la realidad del ocio juvenil, con el fin de dar cumplimiento a nuestros objetivos de investigación.

\section{Discusión}

Tras una revisión analítica de las investigaciones objeto de estudio, los resultados más sobresalientes en cada una de las dimensiones analizadas, han sido los siguientes.

Respecto a la dimensión "TIC", se destaca que la mayor parte de la juventud dispone en el hogar, de un modo u otro, de las principales herramientas para comunicarse o acceder a la información (Ordenador, Internet y teléfono móvil), con tres usos sobresalientes (Martínez Gras \& Espinar Ruiz, 2012; Franco Crespo, 2013): (1) para comunicarse y relacionarse; (2) como forma de entretenimiento y (3) como complemento a los estudios para el proceso de enseñanza-aprendizaje.
Figure 5. Distribution of the sample size

\begin{tabular}{lcc}
\hline & Frequency & Percentage \\
\hline Less than 100 & 8 & 20,0 \\
\hline Between 101 and 500 & 14 & 35,0 \\
\hline Between 501 and 1000 & 6 & 15,0 \\
\hline Between 1001 and 1500 & 7 & 17,5 \\
\hline Between 1501 and 2000 & 1 & 2,5 \\
\hline More than 2001 & 3 & 7,5 \\
\hline Non defined & 1 & 2,5 \\
\hline Total & 40 & 100,0 \\
\hline
\end{tabular}

Source: Personal compilation.

Finally, the research duration is not detailed in most of the analysed articles. When it is detailed $20 \%$ of them range between 1 and 3 months, $17.5 \%$ under a month, and $15 \%$ of articles are over 3 months.

The exposed quantitative results have enabled us to characterize the population and the sample under study as well as defining methodological profiles that have guided the analysed researches. Then, and by way of discussion, qualitative results are exposed. This meta theoretical analysis has enabled us to characterize the reality of youth leisure, in order to comply with our objectives of research.

\section{Discussion}

After an analytical review of the research object of study, the most outstanding results in each of the dimensions analysed, were as follows.

Regarding the "IT" dimension, it is highlighted that most young people have the main tools to communicate or access to the information mainly with computer, Internet and mobile phone at home (Martínez Gras \& Espinar Ruiz, 2012; Franco Crespo, 2013): (1) to communicate and interact; (2) as form of entertainment and (3) as a complement to the studies for the teaching-learning process.

Regarding the first aspect, social networks are a key element as a tool for communication and re- 
En relación al primer aspecto, las redes sociales son un elemento clave como medio de comunicación y relación entre jóvenes, siendo "Tuenti" la red social más utilizada por éstos, y desde edad muy temprana (Colás Bravo, González-Ramírez \& de Pablos-Pons, 2013; Muros, Aragón \& Bustos, 2013; Urquijo Valdivieso, 2011). Actualmente, el uso de estas redes sociales, para el colectivo juvenil, está vinculado al reconocimiento social de sus iguales y a la evitación del aislamiento social, convirtiéndose en un nuevo entorno de socialización para adolescentes y jóvenes; así como un espacio para la construcción de la identidad social con sus iguales (Martínez Gras \& Espinar Ruiz, 2012); con diferencias significativas entre chicos (rol de espectadores, pasivos) y chicas (acceden a la oferta multimedia sin renunciar a quiénes son) (Méndiz Noguero, De Aguilera Moyano \& Borges Rey, 2011).

En el segundo uso referido al entretenimiento, Imaz Bengoetxea (2011) afirma que la mayoría de jugadores de videojuegos tienen parecidas costumbres de ocio frente a los no jugadores, siendo los juegos deportivos los más utilizados y habiendo diferencias significativas entre chicos y chicas, con un incremento de consumo de ellos. Por último, como complemento a los estudios y herramienta en el proceso de enseñanza y aprendizaje, Muros, Aragón y Bustos (2013) señalan que las TIC ayudan a los jóvenes de forma solo esporádica a realizar las actividades del instituto aunque Martínez Gras y Espinar Ruiz (2012) han destacado que la mayor parte de éstos, utilizan el ordenador e Internet en sus estudios de manera frecuente, aunque no lo consideran demasiado fiable (Urquijo Valdivieso, 2011). En este sentido Romo-González, Tarango-Ortíz, Ascencio-Baca y Murgía-Jáquez (2014) afirman que la incorporación de las TIC en el uso cotidiano de los estudiantes puede convertirse en un fenómeno básico que afectará positivamente la manera de abordar los contenidos académicos, siendo ésta una preocupación constante de los docentes en todos los niveles educativos. No obstante, las TIC también tienen sus riesgos para los adolescentes y jóvenes, entre los que se pueden señalar la falta de privacidad y el posible engaño en cuanto a la identidad de los usuarios (Muros, Aragón \& Bustos, 2013), lo que ha de tenerse en cuenta de cara a propiciar espacios y recursos para el buen uso de las mismas. lationship between young people, being the social network "Tuenti" the most used, and from an very young stage (Colás Bravo, González-Ramírez \& de Pablos-Pons, 2013; Muros, Aragón \& Bustos, 2013; Urquijo Valdivieso, 2011). Currently, the use of these social networks, for the youth, is linked to the social recognition of their peers and to the avoidance of social isolation, becoming a new socialization environment for adolescents and young people; as well as an area for the social identity construction with their peers (Martínez Gras \& Espinar Ruiz, 2012); with significant differences between girls (accessing the multimedia offer without sacrificing who they are) and boys (role of passive spectators) (Méndiz Noguero, De Aguilera Moyano \& Borges Rey, 2011).

In the second usage referred to the entertainment, Imaz Bengoetxea (2011) says that the majority of video games players have similar leisure habits as those who do not play, being the most used sports games and having significant differences between boys and girls, with an increase in the boys consumption. Finally, as a complement to the studies and tool in the teaching and learning process, Muros, Aragón and Bustos (2013) showed that IT just help young sporadically to the activities of the High School although Martínez Gras and Espinar Ruiz (2012) have highlighted that most of them, use the computer and Internet regularly for their studies, but do not consider it too reliable (Urquijo Valdivieso, 2011). In this sense Romo-González, Tarango-Ortíz, Ascencio-Baca and Murgía-Jáquez (2014) claimed that the incorporation of IT in the daily use of students can become a basic phenomenon that will positively affect the way of addressing the academic content, and this is a constant concern of teachers at all educational levels. However, ITs also have their risks for adolescents and young people, among those risks, the lack of privacy and possible use of another identity of the users can be mentioned (Muros, Aragón \& Bustos, 2013), that has to be taken into account in order to promote spaces and resources for their proper use.

Meanwhile, in relation to the dimension "Youth social relationships", these relationships are influenced currently by the use of IT as we have seen above, as Bernal and Angulo (2013) exposed,

[ 132 ] ANA FERNÁNDEZ-GARCÍA, MARÍA DE FÁTIMA POZA-VILCHES Y MASSIMILIANO FIORUCCI SIPS - PEDAGOGIA SOCIAL. REVISTA INTERUNIVERSITARIA [1139-1723 (2015) 25, 119-141] TERCERA ÉPOCA 
Por su parte, en lo que se refiere a la dimensión "Relaciones sociales juveniles", hay que destacar que, actualmente, estas relaciones están mediatizadas por el uso de las TIC como hemos visto anteriormente, ya que, como exponen Bernal y Angulo (2013), la mayoría de la juventud utiliza estas herramientas para chatear, estar comunicados y ampliar la red de amistades como nuevas estrategias de relación, de proyección social y de asunción de nuevas competencias sociales, especialmente para jóvenes en dificultad social (Suriá, 2012), ya que pueden favorecer su competencia relacional y mejorar sus habilidades sociales. Por otro lado, si atendemos a las relaciones sociales juveniles más tradicionales, aquellas que se dan "cara a cara", desde diferentes estudios se pone de manifiesto cómo el grupo de iguales influye en el colectivo juvenil tanto para fortalecer estrategias y habilidades sociales positivas que aumentan la confianza intergrupal y la fortaleza de la autoestima colectiva juvenil, como para consolidar pautas de comportamiento desviadas y de hábitos de vida no saludables que pueden provocar acciones de exclusión social. Proponer acciones preventivas y reeducativas en este sentido es fundamental para afianzar modelos de proyección social alternativos y válidos para el desarrollo juvenil, creando referentes apropiados para su desarrollo (Stornaiuolo, DiZio \& Hellmich, 2013; Salguero et al., 2011; Svensson \& Oberwittler, 2010; Moreira, Sánchez \& Mirón, 2010).

Con relación a la dimensión "Valores y jóvenes", se pueden distinguir las investigaciones que analizan los comportamientos y actitudes negativas, frente a aquellas de carácter prosocial que este colectivo desarrolla. En relación a la primera, es importante resaltar que diferentes estudios como los de Pelegrín Muñoz, Garcés de Los Fayos Ruíz y Cantón Chirivella (2010); Espinosa y Clemente (2011); Oudhof van Barneveld y Robles Estrada (2011) o Varela Mallou y otros (2013) pretenden definir un marco de influencia y acción comportamental de la juventud con respecto a los valores que desarrollan (conductas agresivas, menor autocontrol de relaciones sociales, aumento de consumo de drogas, o por el contrario, conductas más respetuosas por el desarrollo de diferentes acciones positivas como la práctica deportiva). En referencia a los valores prosociales, los resultados obtenidos muestran que the main part of youth uses these tools to chat, to be in touch and expand their network of friendship as new relationship strategies, of social projection and of assumption of new social skills, especially for youth in social difficulty (Suriá, 2012), since they can promote their relational competence and improve their social skills. On the other hand, if we consider the more traditional youth social relations, those that happen "face to face", different studies reveal that the peer group influences the youth collective both to strengthen strategies and positive social skills to increase confidence in the collective and the strength of the youth collective self-esteem, as to consolidate diverted behaviour patterns and unhealthy lifestyle habits that can derive into social exclusion. To propose re-education and preventive actions are essential to secure alternative and valid social projection models for youth development, creating accurate referents for their development (Stornaiuolo, DiZio \& Hellmich, 2013; Salguero et al., 2011; Svensson \& Oberwittler, 2010; Moreira, Sánchez \& Mirón, 2010).

In relation to the dimension "Values and youth", the researches that analyse behaviours and negative attitudes towards those of pro-social character developed by this collective can be distinguished. In relation to the first one, it is important to note that different researches like those of Pelegrín Muñóz, Garcés de Los Fayos Ruíz and Cantón Chirivella (2010); Espinosa and Clemente (2011); Oudhof van Barneveld and Robles Estrada (2011) or Varela Mallou and others (2013) are intended to define an influential framework of behavioural action of youth regarding the values developed (aggressive behaviours, lower self-control of social relations, increase of drug abuse, or on the contrary, more respectful behaviour developing various positive actions such as sport practice). Regarding the pro-social values, the obtained results show that benevolence, cooperation, support and collaboration, are associated with more social behaviours. Young people with more pro-social capacity or greater emotional intelligence are valued as better socially adapted (Jiménez \& López-Zafra, 2011). Under this dualism of values, developing an ability for empathy and put yourself in someone's place is an 
la benevolencia, la cooperación, la ayuda y colaboración, se relacionan con comportamientos más sociales. Los jóvenes que presentan mayor capacidad prosocial o mayor inteligencia emocional son valorados como mejor adaptados socialmente (Jiménez \& López-Zafra, 2011). Bajo este dualismo de valores en la juventud, desarrollar la capacidad de empatía y el ponerse en lugar de los demás es misión importante de las instituciones que trabajan con jóvenes para el desarrollo de su personalidad, con la finalidad de incrementar su perspectiva social.

Por último, los resultados de la dimensión "Formas de ocio juvenil" muestran el panorama actual de la realidad juvenil en el ámbito del ocio desde dos subcategorías de análisis: ocio diurno vs. ocio nocturno. Respecto al ocio diurno, López y otros (2012: 60-61) señalan el hecho de que en este tiempo "aparece una serie de actividades que se incrementa sustancialmente en el fin de semana..." y con diferencias significativas respecto al género que las practique. De esta forma, "los hombres realizan más actividades como: deporte, ir de vinos, ir de copas y juegos de mesa, mientras que son más las mujeres que ven televisión o pasan su tiempo de forma ociosa". Desde la práctica de estas actividades se vislumbra que actualmente existe todavía un desconocimiento de forma general por parte de la juventud en torno a las políticas juveniles y a las acciones que a nivel público se organizan para este colectivo, lo que da como consecuencia, una baja participación juvenil en el diseño de éstas (Vidarte \& Vélez, 2012; Pérez-de-Guzmán \& Trujillo, 2011). Pero este desconocimiento no implica que no haya una programación formativa, lúdica y recreativa dirigida a este colectivo aunque es fundamental, como señalan Birkeland, Torsheim y Wold (2009), favorecer la inclusión de la población juvenil en este tipo de dinámicas y actividades, desde actitudes proactivas que beneficien incluso su estado de ánimo. Por otro lado, otros estudios corroboran un espacio de ocio nocturno en el que hay un gran porcentaje de jóvenes que consumen sustancias adictivas durante la noche en fines de semana, y este hecho se incrementa en los universitarios frente a los estudiantes de secundaria (Cortés et al., 2010); con un aumento en el número y abuso, pero también con un aumento de información sobre sus efectos y consecuencias que confirman una modificación en los patrones de important mission for institutions working with youth for the development of their personality, in order to increase their social perspective.

Finally, results of the dimension "Forms of youth leisure" show the current landscape of youth reality in leisure from two sub-categories of analysis: dayltime vs. nightlife entertainment. Regarding the daytime entertainment, López and others (2012: 60-61) point to the fact that at this time "a series of activities that substantially increases in the weekend..." and with significant differences in relation to the genre that practice them. In this way, "men do more activities as: practice sport, drinking wine, have a drink and board games, while women prefer to watch TV or spend their time in idle manner". From the perspective of this activities it can be seen that there is still a lack of general knowledge among young people over youth policies and actions organized for them at a public level, which provoke a lower youth participation in their design (Vidarte \& Vélez, 2012; Pérez-de-Guzmán \& Trujillo, 2011). But this lack of knowledge does not mean that a lack of formative, leisure and recreational programming focused on them. However, as Birkeland, Torsheim and Wold (2009) said, it is essential to encourage the inclusion of the youth population in this type of dynamics and activities, starting from proactive attitudes that can even improve their mood. On the other hand, other studies confirm a night leisure area in which there is a large percentage of young people who consume addictive substances during weekends, which increases in university students compared with high school students (Cortés et al., 2010); with an increase in the number and abuse, but also an increase of information about its effects and consequences which confirm a change in patterns of youth consumption (Ballester \& Gil, 2009). Lomba, Apóstolo and Mendes (2009), also linked the consumption of these substances with the sex practice in these areas of nightlife. Finally, Giménez, Cortés and Espejo (2010), after analysing perception of young people, parents and policemen have over open-air drinking, confirm that they all identify the "openair drinking" as a time for drink. The group of young stated that it is important to do it with friends. Facing this problem, it is essential to con-

[ 134 ] ANA FERNÁNDEZ-GARCÍA, MARÍA DE FÁTIMA POZA-VILCHES Y MASSIMILIANO FIORUCCI SIPS - PEDAGOGIA SOCIAL. REVISTA INTERUNIVERSITARIA [1139-1723 (2015) 25, 119-141] TERCERA ÉPOCA 
consumo juvenil (Ballester \& Gil, 2009). Lomba, Apóstolo y Mendes (2009), además, vinculan el consumo de estas sustancias con la práctica de relaciones sexuales en estos espacios de ocio nocturno. Por último, Giménez, Cortés y Espejo (2010), tras analizar las percepciones que jóvenes, padres-madres y policías tienen sobre el botellón, confirman que hay unanimidad en la muestra a la hora de identificar el "botellón" como el acto de beber. El grupo de jóvenes matiza que es importante hacerlo en compañía de amigos. Ante esta problemática, es fundamental plantear líneas de intervención eficaces que contrarresten los efectos de un consumo no responsable y fomentar formas de ocio saludables (Giménez, Cortés \& Espejo, 2010).

\section{Conclusiones y propuestas de futuro}

Presentada la discusión de resultados, podemos concluir que la aportación que este estudio metateórico ofrece a la comunidad investigadora es la de presentar un mapa de tendencias que caracteriza la situación actual del colectivo juvenil (especialmente aquel con problemática social añadida) en relación al ocio y que ha de orientar la acción profesional y el desarrollo de buenas prácticas. Esta silueta del ocio juvenil queda caracterizada de la siguiente forma:

Con relación al uso de las TIC, cabe destacar la gran accesibilidad que tienen los adolescentes y jó-

Figura 6. Mapa de tendencias

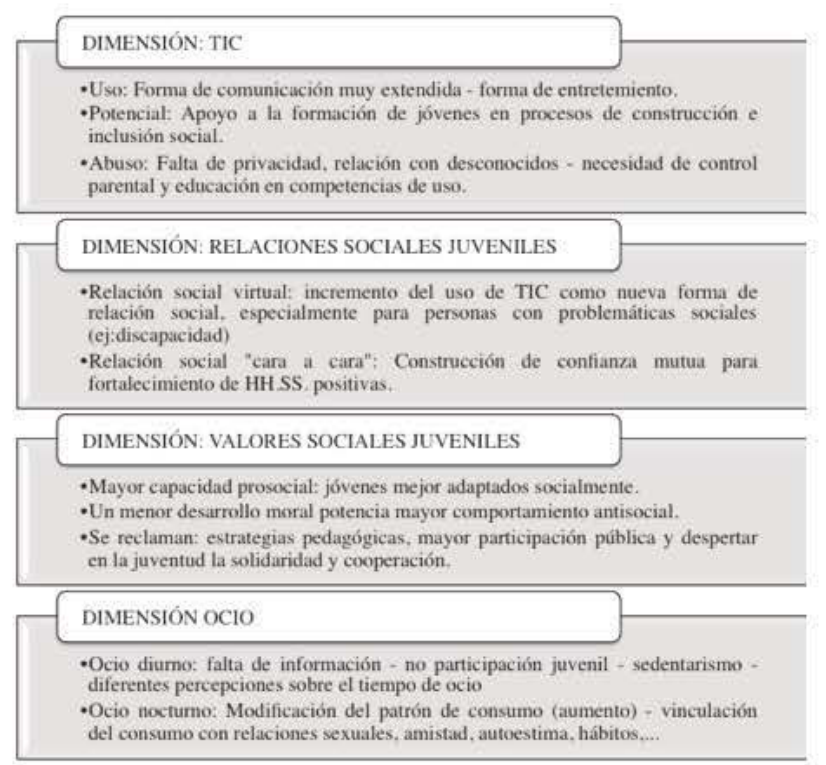

Fuente: Elaboración propia. sider effective lines of intervention that counteract the effects of non-responsible consumption and promote healthy forms of leisure (Giménez, Cortés \& Espejo, 2010).

\section{Conclusions and proposals for the future}

Once the results discussion is presented, we can conclude that the contribution that this meta theoretical offers to the research community is a map of trends which characterising the current situation of the collective youth (especially one with added social problems) in relation to leisure and who should guide professional action and the development of good practices. This silhouette of youth leisure is characterized in the following way:

In relation to the use of $\mathrm{IT}$, it is worth to underline the great accessibility that adolescents and young people have to new technologies, es-

Figure 6. Map of trends

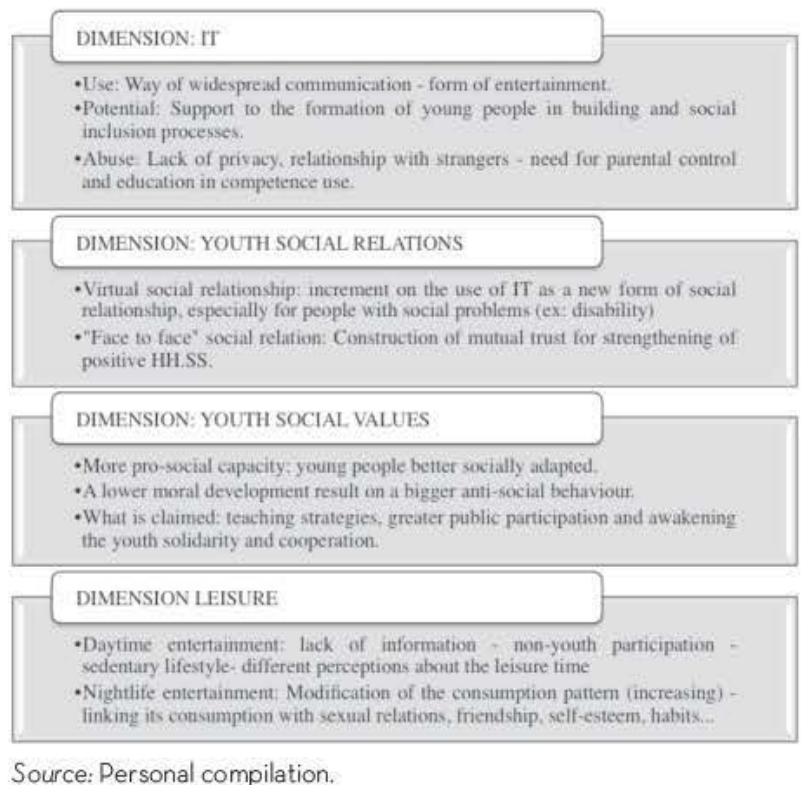

Source: Personal compilation. 
venes a las nuevas tecnologías, sobre todo al uso del teléfono móvil. Es una forma de comunicación muy extendida entre ellos, no solo para hablar sino también por medio del envío de mensajes, llamadas perdidas... por otro lado, sin lugar a dudas las TIC constituyen una nueva forma de entretenimiento (videojuegos, radio, música...). Así mismo contienen un gran potencial porque ayudan a formar a la juventud en procesos de construcción e inclusión social, evitando el aislamiento y potenciando la socialización y el reconocimiento social. Sin embargo, un abuso de la TIC puede desencadenar peligros como las relaciones con desconocidos, mediante el engaño en la identidad de los usuarios, la falta de privacidad... Es necesario educar en competencias con respecto a las TIC, así como el control parental en los menores de edad.

En el ámbito de las relaciones sociales juveniles, se identifican dos tendencias claras; las vinculadas a potenciar las posibilidades que ofrecen las relaciones sociales virtuales en tanto en cuanto son herramientas que favorecen la proyección social juvenil a gran escala con el fin de ampliar la red social con facilidad sin prácticamente moverse del contexto de referencia, y aquella tendencia en la que se vinculan los estudios de las relaciones sociales "cara a cara", sus oportunidades y limitaciones para favorecer el desarrollo de comportamientos prosociales, la mejora de la autoestima y el fortalecimiento de la confianza mutua para afianzar la red social juvenil.

En relación a los valores, los datos han revelado que los jóvenes que presentan una mayor capacidad prosocial están mejor adaptados socialmente. En contraposición, aquellos que presentan un mayor comportamiento antisocial, poseen en menor medida un óptimo desarrollo moral. En las investigaciones analizadas se reclama una serie de medidas en la educación moral de esta cohorte de edad. A continuación se exponen las más relevantes: "promover estrategias pedagógicas tendentes a reforzar la igualdad de género"; "una mayor participación en la vida pública y política”; y "despertar en la juventud el sentimiento de solidaridad y colaboración".

Por último, la caracterización del ocio juvenil, ya sea diurno o nocturno, proporciona a los profesionales tanto conocimiento de la realidad juvenil con la que se ha de trabajar como pautas de interven- pecially to the use of mobile phones. Among them is a widespread way of communication, not just to speak but also to send messages, make missed calls... on the other hand, undoubtedly the ITs are a new form of entertainment (video games, radio, music...). It also has a great potential because they contribute to educate young people in processes of building and social inclusion, avoiding isolation and promoting socialization and social recognition. However, an abuse of ITs can trigger some dangers as relations with strangers, being tricked with false identities, lack of privacy... It is necessary to educate them regarding the use of IT, as well as the parental control of minors.

The field of youth social relationships, two clear trends are identified; those linked to enhance the possibilities that social relationship offer as tools that favour the youth social projection on a large scale in order to easily expand the social network without leaving the reference context, and the tendency linked with studies "face to face" of social relations, its opportunities and limitations when boosting the development of pro-social behaviours, the improvement of self-esteem, and the strengthening of mutual trust to consolidate the youth social network.

Regarding the values, data have revealed that more pro-social young people are better socially adapted. In contrast, those who have a more antisocial behaviour, have a less optimal moral development. The analysed researches claim a series of measures in the moral education of this age cohort. The most important are: "to promote pedagogical strategies to reinforce gender equality"; "a greater participation in public and political life"; and "to awake in youth the feeling of solidarity and collaboration".

Finally, the characterization of youth leisure, either daytime or night, gives professionals both knowledge of the youth reality they have to work with, and guidelines for intervention that minimize risks and boost the youth collective chances towards a leisure practice educational, creative, healthy, and responsible.

On the other hand, given the main results from different articles analysed, we propose different lines of future work that would be taken into account for the professional practice and work with 
ción que minimicen riesgos y potencien las posibilidades del colectivo juvenil en pro de una práctica de ocio educativa, creativa, saludable y responsable.

Por otro lado, tomando como base los resultados que se han resaltado desde los diferentes artículos analizados, se proponen diversas líneas de trabajo futuro que sería adecuado tener en cuenta en la práctica profesional y en el trabajo con el colectivo juvenil con el fin de mejorar su calidad de vida y favorecer su desarrollo normalizado. A continuación se presentan diferentes propuestas:

Se debería seguir trabajando para descubrir el propósito y la finalidad primordial que nos permita analizar con más precisión el por qué los y las jóvenes precisan de dispositivos tecnológicos y para qué los usan. Sería conveniente también conocer la evolución de la brecha digital existente entre ellos, especialmente el gap que se constata entre los del Norte y los del Sur.

Es necesario investigar si realmente la convivencia virtual permitirá que las nuevas generaciones construyan un mundo solidario generador de nexos sociales fuertes en la juventud, respetuosa con el medioambiente, plural e inclusiva. Es de interés destacar la importancia del capital de las familias y comunidades en las relaciones, prácticas y cultura compartida en y con las redes sociales.

Así mismo es muy relevante abogar por un civismo en red apoyado en experiencias sociales y lúdicas que refuercen el compromiso cultural y social.

La televisión puede tener un efecto enormemente constructivo en la difusión de valores que hagan atractivo el aprendizaje y necesario el esfuerzo por conseguirlo. Compartir y enseñar la televisión será más eficaz que restringirla o limitarla.

Por su parte, educar las emociones se ha convertido en una tarea cada vez más necesaria en el ámbito educativo. El esfuerzo futuro deberá centrarse en el "cómo" deben ser las tareas y actividades con que se aborde cada contenido para que se produzca el cambio que se pretende. Se debería trabajar en la línea de reconocer a la juventud como un colectivo que tiene sus propios intereses, demandas y capacidades de razonamiento.

Otra propuesta relevante que se plantea es la de diseñar campañas de información, sensibilización, the collective youth in order to improve their quality of life and promote their standardized development. Some proposals are exposed bellow:

It have to keep working to discover the purpose and main objective that will allow us to analyse more accurately why young people require technological devices and for what they use them. It would also be desirable to know the evolution of the digital divide between them, especially between those form the North and those from the South.

It is necessary to investigate whether virtual coexistence will finally enable new generations to build a united world that create strong social ties strong in youth, eco-friendly, plural and inclusive. It is relevant to emphasize the importance of the family and community capital in relationships, practices and shared culture and with social networks.

It is also crucial to intercede for a network citizenship supported by social and recreational experiences that strengthen the cultural and social commitment.

Television can have very positive effect on the diffusion of values that make learning attractive and necessary the effort to obtain it. Share and teach television will be more effective than restrict or limit it.

Teaching emotions has become a more and more necessary task in the education field. Future efforts should focus on "how" should be the tasks and activities that address each content for the intended change to occur. We should work for recognizing youth as a collective with their own interests, demands and reasoning abilities.

Another important proposal that emerges is the design of campaigns of information, awareness-raising, communication and dissemination of different recreational, playful and healthy, actions oriented to the collective youth from participatory designs that arise from their needs and demands and that enhance their quality of life.

Finally, we intend to work towards good practices that minimize the effects of an unhealthy nightlife. In this sense, it is essential to develop prevention campaigns; of alternatives adapted to various problems; of real actions able to counte- 
comunicación y difusión de las diferentes acciones recreativas, lúdicas y saludables, que están orientadas al colectivo juvenil desde diseños participativos que surjan de sus necesidades y demandas y potencien su calidad de vida.

Por último, se propone trabajar en pro de buenas prácticas que apuesten por minimizar los efectos de un ocio nocturno poco saludable. En esta línea es fundamental desarrollar campañas preventivas, de alternativas adaptadas a las diferentes problemáticas, de acciones reales capaces de contrarrestar los efectos de un consumo excesivo de drogas y alcohol abogando no tanto por consumo cero (filosofía de acción irreal dada la casuística actual del ocio juvenil), sino por opciones de consumo responsable en pro de hábitos de vida saludable para la mejora de la calidad del ocio juvenil. ract the effects of excessive consumption of drugs and alcohol but not claiming a zero consumption (philosophy of action unrealistic given the current case of the youth leisure), but by choosing a responsible consumption for a healthy lifestyle in order to improve the quality of the youth leisure.

\section{REFERENCIAS BIBLIOGRÁFICAS/ BIBLIOGRAPHIC REFERENCES}

Ballester, R. \& Gil, M.D. (2009). ¿Por qué los jóvenes se dan atracones de alcohol los fines de semana? Estudio sobre creencias y actitudes relacionadas con este patrón de consumo y diferencias de género. Revista de Psicopatología y Psicología Clínica, 14, (1), 25-35. doi: 10.5944/rppc.vol.14.num.1.2009.4064

Bernal, C. \& Angulo, F. (2O13). Interacciones de los jóvenes andaluces en las redes sociales. Comunicar, 40 (20), 25-30. doi: 10.3916/c40-2013-02-O2

Birkeland, M.S., Torsheim, T., Wold, B. (2009). A longitudinal study of the relationship between leisure-time physical activity and depressed mood among adolescents. Psychology of Sport and Exercise,10, 25-34. doi: 10.1016/j.psychsport.2008.01.005

Colás Bravo, P., González-Ramírez, T. \& de Pablos-Pons, J. (2013). Juventud y redes sociales: Motivaciones y usos preferentes. Comunicar, 40 (20), 15-23. doi: 10.3916/c40-2013-02-01

Cortés del Moral, R. (2000). La filosofía y la racionalidad contemporánea. Guanajuato: Universidad de Guanajuato.

Cortés, M.T., Espejo, B., Martín, B. \& Gómez, C. (2010). Tipologías de consumidores de alcohol dentro de la práctica del botellón en tres ciudades españolas. Psicothema, 22 (3), 363-368.

Cuenca, M. (1998). El ocio como ámbito educativo: reflexiones desde el deporte. Educación física e deporte no século XXI. VI Congreso Galego de Educación Física (1996. A Coruña). Congreso Internacional de Intervención en Conductas Motrices Significativas. A Coruña: Universidade, 185-203

Dávila, G. (2006). El razonamiento inductivo y deductivo dentro del proceso investigativo en ciencias experimentales y sociales. Laurus, 12, 180-205.

Espinosa, P., Clemente, M. (2011). La medida del comportamiento antisocial en adolescentes y jóvenes: desarrollo del Inventario de Comportamientos Antisociales (ICA). Revista de Psicología social: International Journal of Social Psychology, 26 (23), 223-240. doi:10.1174/O21347411795448974

Franco Crespo, A. (2013). El uso de la tecnología: determinación del tiempo que los jóvenes de entre 12 y 18 años dedican a los equipos tecnológicos. Aiesad Ried, 16 (2), 107-125. doi: 10.5944/ried.16.2.9908

Giménez, J.A., Cortés, M.T. \& Espejo, B. (2010). Consumo de alcohol juvenil: una visión desde diferentes colectivos. Salud y drogas, 10 (1), 13-34. 
Gómez Villalpando, A. (2009). La teoría y la metateoría en el campo educativo. X Congreso Nacional de Investigación Educativa. Área 8: filosofía, teoría y campo de la educación. Veracruz, México, 21 al 25 de septiembre de 2009.

Imaz Bengoetxea, J. I. (2011). Pantallas y educación: adolescentes y videojuegos en el País Vasco. Teoría de la Educación. Revista Interuniversitaria, 23 (1), 181-200.

INJUVE (2012). Informe de la juventud de España. Ministerio de Sanidad, Servicios Sociales e Igualdad. Madrid: España

Jiménez, M. I. \& López-Zafra, E. (2011). Actitudes sociales y adaptación social de adolescentes españoles: el papel de la inteligencia emocional percibida. Revista de Psicología Social: Internacional Journal of Social Psychology, 16 (1), 105-117. doi: 10.1174/021347411794078417

Lomba, L., Apóstolo, J. \& Mendes, F. (2009). Consumo de drogas, alcohol y conductas sexuales en los ambientes recreativos nocturnos de Portugal. Adicciones, 21 (4), 309-326

López, A., López, M., González, I. \& Fernández, E. (2012). El ocio y los enfoques de aprendizaje en estudiantes universitarios de enfermería. Revista de Investigación Educativa, 30 (1), 53-70. doi: 10.6018/rie.30.1.111581

Martínez Gras, R. \& Espinar Ruíz, E. (2012). Adolescentes y Tecnologías de la Información y la Comunicación en España. OBETS. Revista de Ciencias Sociales, 7 (1), 109-122. doi: 10.14198/OBETS2012.7.1.05

Méndiz Noguero, A., De Aguilera Moyano, M \& Borges Rey, E. (2011). Actitudes y valoraciones de los jóvenes ante la TV móvil. Comunicar, 36 (23), 77-85. doi: 10.3916/C36-2011-02-08

Montes, P. (2008). Políticas locales de juventud. Criterios, herramientas y recursos. Barcelona: Diputación de Barcelona.

Moreira, V., Sánchez, A. \& Mirón, L. (2010). El grupo de amigos en la adolescencia. Relación entre afecto, conflicto y conducta desviada. Boletín de Psicología,100, 7-21.

Muros, B., Aragón, Y.\& Bustos A. (2013). La ocupación del tiempo libre de jóvenes en el uso del tiempo libre en el uso de videojuegos y redes. Comunicar, 40 (20), 31-39. doi: 10.3916/C40-2013-02-03

Oudhof van Barneveld, H. \& Robles, E. (2011). Jóvenes y límites sociales: el mito de la rebeldía. Enseñanza e Investigación en Psicología, 16 (1), 143-154.

Pelegrín Muñoz, A., Garcés de los Fayos Ruíz, E. J. \& Cantón Chirivella, E. (2010). Estudios de conductas prosociales y antisociales. Comparación entre niños y adolescentes que practican y no practican deporte. Informació psicológica, 99, 64-78.

Pérez-de-Guzmán, V. \& Trujillo, J.F. (2011). Educar e investigar de manera participativa: la implicación asociativa juvenil en las actividades de ocio y tiempo libre. Tiempo de Educar, 12 (24), 235-256.

Popper, K. R. (1983). Conjeturas y refutaciones. Buenos Aires: Eds. Paidós.

Romo-González, J., Tarango-Ortiz, J., Ascencio-Baca, G. \& Murguía-Jáquez, P. (2014). Medición de la cibercultura estudiantil, confiabilidad y validez de una escala aplicada: caso de la Universidad Autónoma de Chihuahua. Anales de documentación, 17 (1), 1-12. doi: 10.6018/analesdoc.17.1.173011

Salguero, J.M., Fernández, P., Ruiz, D., Castillo, R. \& Raquel, R. (2011). Inteligencia emocional y ajuste psicosocial en la adolescencia: El papel de la percepción emocional. European Journal of Education and Psychology, 4 (2), 143-152. doi: 10.1989/ejep.v4i2.84

Sarrate Capdevila, M. (coord.) (2014). Programas de animación sociocultural. Madrid: UNED.

Stornaiuolo, A., DiZio, J. K. \& Hellmich, E. A. (2013). Desarrollando la comunidad: jóvenes, redes sociales y escuelas. Comunicar, 40, (XX), 79-88. doi: 10.3916/C40-2013-02-08

Suriá, R. (2012). Redes sociales online y su utilización para mejorar las habilidades sociales en jóvenes con discapacidad. Escritos de Psicología - Psychological Writings, 5 (3), septiembre-diciembre, 16-23. doi: $10.5231 /$ psy.writ.2012.1809

Svensson, R. \& Oberwittler, D. (2010). It's not the time they spend, it's what they do: The interaction between delinquent friends and unstructured routine activity on delinquency. Findings from two countries. Journal of Criminal Justice, 38, 1006-1014. doi: 10.1016/j.jcrimjus.2010.07.002

Urquijo Valdivieso, J. I. (2011). Los jóvenes y las nuevas tecnologías. Almenara, 3 (primer semestre), 10 págs. 
Varela Mallou, J., Marsillas Rascado, S., Isorna Folgar, M. \& Rial Boubeta, A. (2013). Las percepciones y el dinero disponible en el consumo de drogas en adolescentes. Health and Addictions, 13 (1), 67-78.

Vidarte, J.A. \& Vélez, C. (2012). Caracterización de la realidad juvenil de Caldas (Colombia): Área de Deporte, Recreación y Tiempo libre. Apunts. Educación Física y Deportes, 110, 40 trimestre, 78-88. doi: 10.5672/apunts.2014-0983.es.(2012/4).110.09

\section{Notas}

${ }^{1}$ El texto presentado se vincula al subproyecto "De los tiempos educativos a los tiempos sociales: Ocio, formación y empleo de los jóvenes en dificultad social" (EDU2012-39080-C07-07) incluido dentro del Proyecto de Investigación "De los tiempos educativos a los tiempos sociales: "La construcción cotidiana de la condición juvenil en una sociedad de redes. Problemáticas específicas y alternativas pedagógico-sociales" (proyecto coordinado EDU2012-39080-C07-00), cofinanciado en el marco del Plan Nacional I+D+i con cargo a una ayuda del Ministerio de Economía y Competitividad, y por el Fondo Europeo de Desarrollo Regional (FEDER, 2007-2013)

2 The paper presented is related to two research project co-founded by the European Regional Development Funds (ERDF, 2007-2013) and the Ministries of Education and Science and Economy and Competitiveness (Code EDU201239080-C07-00 a 07), in the frame of the National Plan of I+D+i; from which the prof. Dr. José Antonio Caride is IP, from the Universidad de Santiago de Compostela: "From Educational to Social Times.Leisure, Education and Employment for Youth in Social Difficulty" (TETOSO) "From educational to social times: the daily young building of the young condition into a network society. Specific problems and socio-pedagogical alternatives." (RESORTES)

\section{CÓMO CITAR ESTE ARTÍCULO / HOW TO CITE THE ARTICLE}

Fernández-García, A., Poza-Vilches, M. F. \& Fiorucci, M. (2015). Análisis Metateórico sobre el Ocio de la juventud con problemas sociales. Pedagogía Social. Revista Interuniversitaria, 25 119-141. doi:10.7179/PSRI_2015.25.6

Fecha de recepción del artículo / received date: 21.VI.2O14

Fecha de revisión del artículo / reviewed date: 24.VI.2014

Fecha de aceptación final / accepted date: 18.X.2014

\section{DIRECCIÓN DE LA AUTORA/ AUTHOR'S ADDRESS}

Ana Fernández-García, Facultad de Educación, Departamento de Teoría de a Educación y Pedagogía Social, Universidad Nacional de Educacion a Distancia. Campus Norte, Juan del Rosal 14, 28040, Madrid, España. Dirección de correo/e-mail: anafernandez@bec.uned.es

María de Fátima Poza-Vilches, Facultad de Ciencias de la Educación, Departamento de Métodos de Investigación y Diagnóstico en Educación, Universidad de Granada. Campus de Cartuja s/n, 18071, Granada, España. Dirección de correo/e-mail: fatimapoza@ugr.es

Massimiliano Fiorucci. Settore Scientifico Disciplinare M-PED/OI. Dipartimento di Scienze della Formazione, Universitá degli Studi. Roma TRE. Via Milazzo 11/B. Roma, Italia. Dirección de correo/e-mail: massimiliano.fiorucci@uniroma3.it

PERFIL ACADÉMICO / ACADEMIC PROFILE

Ana Fernández-García. Becaria FPI del Departamento de Teoría de la Educación y Pedagogía Social de la Universidad Nacional de Educación a Distancia (UNED). Diplomada en Educación Social por la UNED, Pre-

[ 140 ] ANA FERNÁNDEZ-GARCÍA, MARÍA DE FÁTIMA POZA-VILCHES Y MASSIMILIANO FIORUCCI

SIPS - PEDAGOGIA SOCIAL. REVISTA INTERUNIVERSITARIA [1139-1723 (2015) 25, 119-141] TERCERA ÉPOCA 
mio Extraordinario Fin de Carrera. Licenciada en Pedagogía por la UNED. Máster en Innovación e Investigación en Educación por la UNED. Premio Extraordinario Fin de Máster en la categoría de Ciencias Sociales y Jurídicas. Actualmente es becaria del proyecto I+D denominado "De los tiempos educativos a los tiempos sociales. Ocio, formación y empleo de los jóvenes en exclusión social".

María de Fátima Poza-Vilches. Profesora asociada en el Departamento de Métodos de Investigación y Diagnóstico en Educación de la Facultad de Ciencias de la Educación de la Universidad de Granada (España) donde desempeña su labor docente sobre metodología de evaluación de programas en educación (reglada y no reglada). Su labor de investigación está enfocada al ámbito de la evaluación de programas relacionados con la educación social y educación medioambiental desde procesos de investigación-acción. Respecto a su práctica profesional, ésta se centra en el desarrollo de estrategias de intervención sociocultural para el colectivo juvenil. Ha publicado varios libros y artículos en revistas de educación social y ambiental.

Massimiliano Fiorucci. Profesor titular en el Departamento de Ciencias de la Formación de la Universidad Roma Tre, donde enseña Pedagogía Social e Intercultural y en la que también es coordinador científico de CREIFOS (Centro de Investigación sobre la Educación Intercultural y la Formación para el Desarrollo) (www.creifos.org). Desde diciembre de 2013 es coordinador responsable de la titulación de primer ciclo en Ciencias de la Educación du su Departamento. Desde 2007 a 2011 fue coordinador del Doctorado de Investigación en Pedagogía, y de 2006 a 2013 fue secretario de la Sociedad Italiana de Pedagogía (SIPED). EI foco de sus investigaciones se centra principalmente en la pedagogía intercultural, con especial atención a la cuestión de la mediación cultural también con enfoque en la literatura migrante. Se ocupa, además, de educación y formación de adultos, de análisis de las necesidades formativas, de calidad de la formación, de formación en las organizaciones y de pedagogía social. 
